\title{
Reflections on Mortgage Keynesianism: Applying Prasad's (2012) Abundance and the Paradox of Poverty in the United States to Contemporary China
}

\author{
Xueli Huang ${ }^{1}$ \\ Published online: 11 May 2020 \\ (c) Springer Science+Business Media, LLC, part of Springer Nature 2020
}

The USA is unique among advanced Western democracies for the depth and expanse of its poverty (Desmond \& Western, 2018). Many researchers believe that it is the result of the American government's laissez-faire approach to the economy. But this explanation did not fully convince Monica Prasad. In her book, "The land of too much: American abundance and the paradox of poverty," Prasad offers a nuanced explanation by providing a subversive view of history based on detailed historical research. Contrary to popular opinion, Prasad argues that the USA is not a laissezfaire country. Rather, the government exerts more control and intervenes in the market more than many European countries. Under the sway of American agrarian statism, the US government implements a series of tax and financial policies to stimulate a consumer society, which inhibits the establishment of the public welfare states and leads to increased poverty in the USA.

In the current review, I expand upon a number of points raised by Prasad (2012). But first, I begin with a review of her book and identify its specific research contributions. I then ponder the implications that can China draw from this book in addressing the construction of a welfare society. My conclusion is that the existing research has overlooked some of these critical issues, especially in terms of the applicability of Western-focused research to the case of China.

\section{Basic Content of the Book}

As one of the world's super-rich countries, the poverty rate of the USA has remained stubbornly high for half a century (US Census Bureau, 2017), resulting in an intriguing paradox between the coexistence of American wealth and poverty. Prasad (2012) provides much needed insight into this troubling contradiction in her book. From

Xueli Huang

freedom_xueli@163.com

1 School of Sociology, Huazhong University of Science and Technology, Wuhan 430074, People's Republic of China 
detailed historical data, Prasad puts forward her theory: A state's approach to consumption is the best predictor of whether it will develop an extensive public welfare state that reduces poverty. Prasad musters support for her argument in the three parts of the book.

In the first part, Prasad (2012) shows that the US government actually has a stronger administrative force than Europe by analyzing a series of strict controls on imported drugs by the Food and Drug Administration (FDA). However, such intervention has not led the USA to develop into a welfare state like many developed countries in Europe. Instead, the USA has fallen into extreme inequality. Prasad argues that the reason that inequality has soared despite extreme interventions is due to how the US government intervened, especially in terms of the state's attitude to consumption. Relying upon historical analysis, Prasad argues that the US government has pursued a consumption-oriented economic growth model since the Great Depression, which shapes a different development path of the USA. As a British colony, the USA implemented a series of colonial power systems that are conducive to economic growth which have boosted the prosperity of the US economy and introduced products to a significant share of the world's economy. However, the paradox is that the living standards of American citizens have not improved in line with the economy. This is especially true of farmers. Extremely high agricultural production coexisted with low prices, causing a large number of independent farmers to go bankrupt and fall into poverty. Because votes in agricultural districts play an important role in the political structure of the USA, the country has developed a "demand-side" national strategy. The demand-side model focuses on two policies: a progressive tax policy and a loose financial credit policy which are aimed at narrowing the income gap and stimulating demand in the housing market. However, Europe, which was also facing an economic crisis, adopted a "supply side" strategy. These two strategies ultimately have opposing effects on the formation of the welfare state.

In the second part of the book, Prasad (2012) discusses the social origins of "progressive taxes" and their deterring effect on the establishment of welfare state. Although the USA has a progressive tax structure, it is the only advanced industrial country without a national sales tax. Moreover, while many of states within the USA do impose sales taxes, the total sales tax burden is less than one half of the sales tax burden found in most other countries (Hines Jr, 2007).

Why did the USA reject a national sales tax? Prasad (2012) notes that, on the one hand, the regressive nature of business taxes does not benefit low-income people, as the poor pay a greater proportion of their income for the necessities of life than do the wealthy. This policy came about because, during the Great Depression, lowincome farmers were facing a serious agricultural crisis. As such, Democrats rallied against steep sales taxes and won support from Congress. On the other hand, income taxes have been a particularly effective weapon against large corporations. Farmers and workers united in support of the government's collection of income taxes, and the USA finally established a national tradition of imposing high taxes on the rich.

Why did the rich agree to these high taxes? Prasad (2012) argues that the government gave large corporations a loophole through tax incentives, which can be seen as a compromise under the pressure of farmers and industrial groups. However, not 
all companies can enjoy tax benefits unless they pay accident insurance and medical insurance for employees to private insurance companies. The tax incentive was supported by business owners since they found that paying extra benefits for employees can also increase employee satisfaction and loyalty. The tax incentive was established in the Revenue Act of 1924. The law encourages the adoption of formal private health and pension insurance programs, thereby strengthening America's dependence on private benefits. Since then, company-provided private health care programs and pension plans have expanded. The government's role in providing pensions and health care has been squeezed out by enterprises, and the social welfare systems have gradually diminished. Ironically, at the same time this was occurring in the USA, public welfare was replacing private welfare systems in Europe.

In the third part of the book, Prasad (2012) examines how early financial regulation policies prevented the USA from growing into a welfare state. During the Great Depression, the USA launched a housing mortgage policy that was extremely favorable for consumers. For example, the National Housing Act of 1934 legalized home purchase loans, giving way to various credit instruments including home mortgages and home improvement loans. These financial instruments created a credit housing model in the USA and have spawned a type of "mortgage Keynesianism" centered on credit-driven housing consumption. Credit has become a core element in organizing people's lives, and credit consumption has entered millions of households.

Despite these favorable conditions, racial and gender discrimination persisted in the USA Prasad (2012) notes that, with the rise and success of the Civil Rights Movement, credit equalization became an important indicator of American democracy and greatly improved the purchasing power of the American people. Although the establishment of credit-based consumption is good news for those who have the ability to borrow, for those who are unable to repay these loans, it leads to excessive borrowing. Accordingly, the poor loose out by being unable to repay their loans and having no social assistance. In short, the democratization of credit undermined the possibility for the USA to become a welfare state, and eventually led some people in the USA to fall into poverty. As Vance (2016) mentioned in his personal memoirs (page number: 175-176 in the e-book version, Chapter 9), "we spend our way into the poorhouse. We buy giant TVs and iPads. Our children wear nice clothes thanks to high-interest credit cards and payday loans. We purchase homes we don't need, refinance them for more spending money, and declare bankruptcy, often leaving them full of garbage in our wake."

\section{Contribution of the Book}

As an outstanding sociologist, Prasad (2012) excavates new theoretical explanations from complex historical fiscal and tax policies. The result is a unique view on the paradox between wealth and inequality in the USA. Accordingly, the main contributions of this book can be summarized as follows.

Firstly, this work provides a new explanation for the origins of the paradox of poverty in the USA. In the field of comparative political economics, researchers have often wondered why the USA has a larger gap between the rich and the poor 
than is seen in other developed countries. The existing literature puts forward the following theories as potential explanations: (1) Class-based approaches argue that the unique pro-capitalism mantra in the USA makes it difficult to create a welfare state. (2) Institution-based approaches hold that the free market economic system places more emphasis on fair market transactions which, in turn, creates more inequality. (3) Cultural approaches posit that the USA favors the national culture of market economy and rejects the thought of socialism. (4) Race-based approaches argue that the racial division present in the USA decreases support for redistribution. (5) Structural-based approaches note that the fragmented power structure in the USA has given American farmers the ability to influence the direction of the welfare state.

There is no doubt that each of these approaches has some explanatory power. Yet each approach fails to effectively answer the reasons for the different development trajectories of the USA and Europe. In the expansive literature, Prasad (2012) believes that the existing research ignores the historical review of the USA in the nineteenth century and, in particular, overlooks the fact that the USA, as an agricultural exporter, has a significantly different agricultural political model from Europe (which is reliant on importing agricultural goods). The differences in historical foundations ultimately shaped the unique consumption characteristics of the USA, hindered the formation of public welfare states, and widened the gap between the rich and the poor.

Secondly, Prasad (2012) subverts the international community's stereotyped understanding of the USA. For a long time, many within the international community assumed that the USA pursues a state policy of passive government intervention (Hall and Soskice, 2001; Liu, 2009). However, as Prasad notes, compared with other countries, the American government has a strong ability to, and often does, intervene in the economy. In the middle and late twentieth century, the USA actually intervened and controlled the market more forcefully than most capitalist countries in Europe. These interventions included areas such as food security, fiscal and tax policy, monetary finance, bank management, and so on. Going back to history, Prasad theorizes about the original motivation of American national interventionism: The political groups of farmers in the late nineteenth century and the early twentieth century finally influenced national policy. In order to cope with the Great Depression and meet the interests and needs of farmers, the country carried out comprehensive interference in the fields of trade, taxation, currency, and promoted the economic model of encouraging consumption mainly through mortgage financing. Prasad called this form of state intervention "mortgage Keynesianism." This is completely different from the active government intervention of "social Keynesianism" seen in European countries. Obviously, from a historical point of view, the development of capitalist countries has not followed a unified linear path. Such insights have prompted a re-examination of the state form of capitalism and increased recognition of the highly regulated "free market" found in the USA.

Thirdly, this book expands the study of fiscal and taxation sociology. Sociology of taxation emerged at the beginning of the twentieth century as a research field. As one of the founders of this field, Schumpeter pointed out that analyzing the causality of financial phenomena is the basis for understanding a series of fundamental 
problems in the social sciences. However, it was not until the 1970s that academic circles began to take a serious look at fiscal and tax sociology, leading to the gradual development of corresponding theories and methods (Martin, Mehrotra, \& Prasad, 2009). Prasad (2012) took over the academic baton in this field by extending analyses to three main areas of tax, finance, and welfare state. Specifically, the book integrates the analysis of economic policy, social structure, and political power mechanisms, highlighting a specific research problem that is inherently interdisciplinary. Accordingly, Prasad demonstrates that the history of fiscal and tax policies in the USA is strongly correlated with levels of the welfare state. In short, this book advances a new vision of research on welfare countries and creates a new model for the analysis of finance and tax sociology.

Despite the strengths of Prasad (2012), there are also some confusing parts. For example, Prasad emphasized that early populism in the USA led to the formation of the American mortgage Keynesianism, which continues to this day. But why did the populism in the USA have such a strong political influence at the time? Does Prasad exaggerate the influence of American farmers? The important role of the working class and capital, as well as its agents, on the establishment of the social welfare system seems to have been ignored. The same critique has been raised by other scholars (Quinn, 2015). In fact, in Europe and the USA, the working class formed a powerful political force in the fight for welfare and equal credit rights. Therefore, it seems a bit one-sided to analyze only from the perspective of farmers (O'Connor, 2013; Quinn, 2015). Nevertheless, these oversights cannot obscure the virtues of Prasad's contributions to the academic world.

\section{Thinking and Enlightenment: The Construction of Welfare Society in China}

China is quite different from the USA in terms of historical foundation, social structure, and political system, but the pursuit of fairness and justice should be independent of national boundaries. Prasad (2012) discusses the causes of large-scale poverty in the USA and identifies "mortgage Keynesianism" as the culprit. At the end of the book, Prasad puts forward a strategy for building the welfare state. This prompts me to think about China's poverty and to reflect on the impact of Prasad's research on Chinese experience and theory.

Since the reform and opening up, the Chinese government has put forward a reform policy centered on economic construction, and adhered to the development strategy of "giving priority to efficiency while giving consideration to fairness," that is, the strategy of "one country, two policies, and division between urban and rural areas" (Lu, 2005). Farmers are in an unequal position as "second-class citizens." The resulting dual social structure has become the source of poverty for Chinese farmers. On the one hand, farmers have to bear high taxes. On the other hand, it is difficult to access the state's welfare supply. For a long time, China's welfare construction mainly existed in the cities. In rural areas, people mainly relied on selfsufficiency and, even if they work in cities without urban hukou, they are not given the same rights and treatment as their urban counterparts (Chen, 2005). 
In recent years, with the continuous development of China's economy (as well as the political and social reforms), the construction of China's welfare system has become more balanced. Firstly, an oppressive agricultural tax was abolished. In 2004, the State Council of the People's Republic of China began to implement a policy to benefit farmers by reducing or exempting agricultural taxes. At the end of 2005, the policy was fixed in the form of law, and 900 million Chinese farmers bid farewell to the history of paying agricultural taxes. Secondly, China has made great efforts to implement targeted poverty alleviation and revitalization policies in rural areas. What is difficult to imagine is that the No. 1 document (the most important document) of the Central Government has focused on the "three rural issues" for 16 consecutive years since 2004. This means that China has begun to transform development strategies, which changes from the urban-rural dual structure system to the system of a comprehensive urban-rural integration (Xu, 2010). Particularly in the 6 years since the Chinese government launched the "Targeted Poverty Alleviation" program in 2013, China's poverty alleviation work has made decisive progress. For example, the number of poor people in the country has greatly decreased from 98.99 million at the end of 2012 to 16.60 million in 2018, and 82.39 million people have been reduced in total; the incidence of poverty has decreased from 10.2 to $1.7 \%$ (http://www.xinhuanet.com/2019-02/15/c_1124120302.htm). However, China still has a long way to go before it compares with other welfare-oriented countries. The situation of rural inequality has been greatly alleviated, but rural people who have moved to cities are still at the bottom of society. For example, in Wuhan, China, some migrant workers who were unable to return home during the lockdown to contain COVID-19 had to live on the streets and in underground passages. This group of homeless people were unable to settle into housing until after their conditions were exposed online.

For a modern developing country, China's welfare system has far exceeded what it was in the early days of reform and opening up. Compared with how the USA uses credit and enterprises as a welfare supply, China seems to have achieved better results in the construction of a welfare state. This is not only due to China's economic growth and overarching socialist system, but also due to the country's strict and standardized system for loans. Most Chinese people respond to possible future life crisis through savings (Chen, 2009). However, from the perspective of fiscal policy in recent years, China is also a consumer-driven credit society, especially in terms of the real estate market. For example, the Chinese government implemented a large-scale housing monetization policy at the beginning of the twenty-first century which has set off a first wave of home loans. Meanwhile, with the rise of Internet finance, credit consumption based on installment payments has entered people's daily lives.

Note that, these changes have also created certain problems, including the P2P explosion incident that occurred from June 2018 to mid-July 2018. In these 50 days, 163 P2P online lending platforms experienced difficulties in cash withdrawal, and the bosses ran away. In addition, student loans have created problems in recent years, as some network-based loan distributors forced college students to provide nude photographs of themselves as collateral to borrow money. These issues have raised public concern and served as a wake-up call for many Chinese. As mentioned 
by Prasad (2012), an excessive reliance on credit finance may increase economic risks, exacerbate the uneven distribution of assets, and widen the gap between rich and poor. This seems to be worthy of reflection by Chinese decision makers to avoid the mistakes of the USA.

In conclusion, Prasad (2012) provides considerable theoretical enlightenment. The book explains the root causes of the gap between rich and poor in the USA through the interplay of economic policy, politics, and social structure. When dealing with the problem of poverty, China can escape the poverty trap by ensuring cooperation between the system and market (Ang, 2016). However, what will be the specific social effects of China's redistribution policy if it successfully avoids the poverty trap? How do political institutions, market mechanisms, and social structures interact to shape the current pattern of wealth distribution in China? These are important issues that have been overlooked in previous studies, yet are crucial to understanding the current relationship between the state, market, and society in China.

Funding This study was supported by the Social science foundation of Hubei province (2018157).

\section{Compliance with Ethical Standards}

Conflict of interest The author declares that she has no conflict of interest.

Ethical approval This article does not contain any studies with human participants performed by any of the authors.

\section{References}

Ang, Y. Y. (2016). How China escaped the poverty trap. New York: Cornell University Press.

Chen, Y. F. (2005). "Migrant workers": Institutional arrangement and identity. Sociological Research, 3, 119-132. (in Chinese).

Chen, Z. W. (2009). Why Chinese people like to save money. IT Time Weekly, Z2, 105. (in Chinese).

Desmond, M., \& Western, B. (2018). Poverty in America: New directions and debates. Annual Review of Sociology, 44, 305-318.

Hall, P. A., \& Soskice, D. W. (2001). Varieties of Capitalism: The institutional foundations of comparative advantage. New York: Oxford University Press.

Hines, J. R., Jr. (2007). Taxing consumption and other sins. Journal of Economic Perspectives, 21(1), 49-68.

Liu, J. (2009). Paradigm of Neo-liberalism and American economic crisis. Social Sciences in Yunnan, 1(4), 105-108. (in Chinese).

Lu, X. Y. (2005). Out of the dilemma of "division between urban and rural areas, one country and two policies". Du shu, 5, 13-16. (in Chinese).

Martin, I. W., Mehrotra, A. K., \& Prasad, M. (2009). The new fiscal sociology: Taxation in comparative and historical perspective. Cambridge: Cambridge University Press.

O'Connor A. (2013). The Land of Too Much: American Abundance and the Paradox of Poverty. By Monica Prasad. Cambridge, MA and London: Harvard University Press. 2012. Pp. xiv, 327. \$39.95, cloth. The Journal of Economic History, 73(4): 1193-1195.

Prasad, M. (2012). The land of too much: American abundance and the paradox of poverty. Cambridge: Harvard University Press. 
Quinn, S. (2015). The land of too much: American abundance and the paradox of poverty. Social Forces, 94(2), e44.

US Census Bureau. (2017). Historical poverty tables: People and families-1959-2016. Washington, DC: Bur. Census.

Vance, J. D. (2016). Hillbilly elegy: A memoir of a family and culture in crisis. New York, NY: HarperCollins.

$\mathrm{Xu}, \mathrm{Y}$. (2010). Chinese development road: from "taking agriculture as the basis to found the nation" to "balancing the urban and rural development". Journal of Huazhong Normal University (Humanities and Social Sciences), 49(4), 1-5. (in Chinese).

Publisher's Note Springer Nature remains neutral with regard to jurisdictional claims in published maps and institutional affiliations. 